\title{
Sustainable Forest Management: An Introduction and Overview
}

\author{
Jorge Martín-García ${ }^{1,2}$ and Julio Javier Diez ${ }^{1}$ \\ ${ }^{1}$ Sustainable Forest Management Research Institute, \\ University of Valladolid - INIA, Palencia \\ ${ }^{2}$ Forestry Engineering, University of Extremadura, Plasencia \\ Spain
}

\section{Introduction}

It is well known that forests provide both tangible and intangible benefits. These benefits may be classified according to ecological values (climate stabilization, soil enrichment and protection, regulation of water cycles, improved biodiversity, purification of air, $\mathrm{CO}_{2}$ sinks, potential source of new products for the pharmaceutical industry, etc.), social values (recreational and leisure area, tradition uses, landscape, employment, etc) and economic values (timber, non wood forest products, employment, etc.). Although forests have traditionally been managed by society, it is expected that the current growth in the world population (now $>7,000$ million people) and the high economic growth of developing countries will lead to greater use of natural resources and of forest resources in particular.

\section{Global forest resources}

The total forest area worldwide, previously estimated at 4 billion hectares, has decreased alarmingly in the last few decades, although the rate of deforestation and loss of forest from natural causes has slowed down from 16 million hectares per year in the 1990s to around 13 million hectares per year in the last decade (FAO, 2011). Nevertheless, the loss of forest varies according to the region, and while the forest area in North America, Europe and Asia has increased in the past two decades (1990-2010), it has decreased in other regions such as Africa and Central and South America, and to a lesser extent Oceania (Fig. 1)

There is growing public concern about the importance of the environment and its protection, as manifested by the fact that the total area of forest within protected systems has increased by 94 million hectares in the past two decades, reaching $13 \%$ of all the world's forests. Moreover, designated areas for conservation of biological diversity and for protection of soil and water account for 12 and $8 \%$ of the world's forests, respectively (FAO, $2010,2011)$. Nevertheless, other statistics such as the disturbing decrease in primary forests ${ }^{1}$ (40 million hectares in the last decade) and the increase in planted forests (up to $7 \%$ of the

\footnotetext{
${ }^{1}$ Forest of native species where there are no clearly visible indications of human activities and the ecological processes have not been significantly disturbed (FAO, 2010)
} 
world's forests) (FAO, 2011) appear to indicate that to achieve forest sustainability, we must go beyond analysis of the changes in the total forest area worldwide.

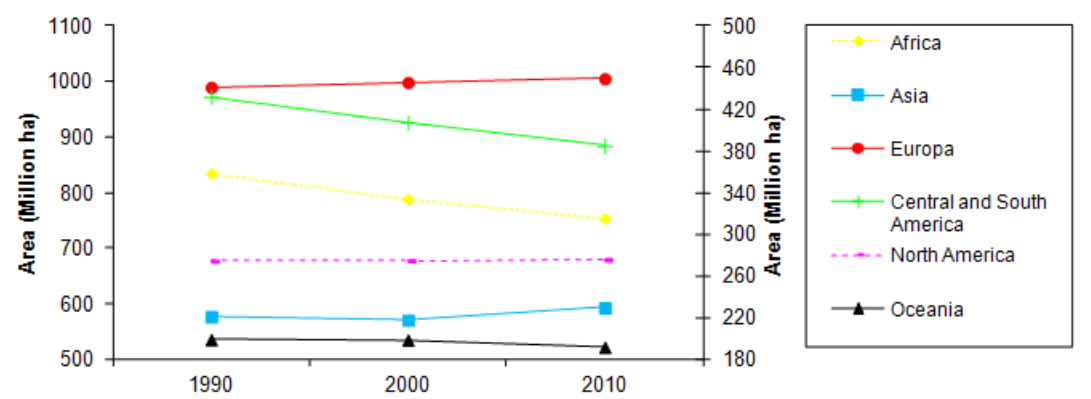

Fig. 1. State of World's Forests 2011 - subregional breakdown (Source: FAO, 2011). Africa, Asia, Europe, Central and South America and North America are represented in the left axis and Oceania in the right axis.

\section{Sustainable forest management}

The concept of sustainability began to increase in importance at the end of the 1980s and at the beginning of the 1990s with the Brundtland report (1987) and the Conference on Environment and Development held in Rio de Janeiro, Brazil, in 1992 (the so-called Earth Summit), respectively. Nevertheless, the need to preserve natural resources for use by future generations had long been recognised.

The negative influence of past use of forest resources, as well as the needs for continued use of these resources for future generations was already noted as early as the $17^{\text {th }}$ century (Glacken, 1976, as cited in Wiersum, 1995). However, it was not until the $18^{\text {th }}$ century that the concept of sustainability was specifically referred to, as follows: "every wise forest director has to have evaluated the forest stands without losing time, to utilize them to the greatest possible extent, but still in a way that future generations will have at least as much benefit as the living generation" (Schmutzenhofer, 1992, as cited in Wiersum, 1995). This first definition was based on the principle of sustainable forest yield, with the main goal being sustained timber production, and it was assumed that if stands that are suitable for timber production are sustained, then non wood forest products will also be sustained (Peng 2000). This assumption focused on the sustainability of the productive functions of forest resources, while other functions such as ecological or socio-economic functions were largely overlooked. This occurred because social demands for forests were mainly utilitarian. However, increased environmental awareness and improved scientific knowledge regarding deterioration of the environment have changed society's values and the global structural policy, which in turn have significantly influenced forest management objectives in $20^{\text {th }}$ century (Wang \& Wilson, 2007). Nevertheless, nowadays more and more researchers think climate change is changing the paradigm and sustainability shouldn't be referred to what we had before.

Although there is no universally accepted definition of SFM, the following concepts are widely accepted: "the process of managing permanent forest land to achieve one or more clearly specified objectives of management with regard to the production of a continuous flow of desired forest products and services without undue reduction of its inherent values and future productivity 
and without undue undesirable effects on the physical and social environment" (proposed by International Tropical Timber Organization: ITTO, 1992), and "the stewardship and use of forests and forest lands in a way, and at a rate, that maintains their biodiversity, productivity, regeneration capacity, vitality and their potential to fulfill, now and in the future, relevant ecological, economic and social functions, at local, national, and global levels, and that does not cause damage to other ecosystems" (proposed by the second ministerial conference for the protection of the forest: MCPFE, 1993). The latter concept harmonizes ecological and socio-economic concerns at different scales of management and for different time periods. Nevertheless, both concepts are just refining the definition of sustainable development gave by the Brundtland Commission (1987) "development that meets the needs of the present without compromising the ability of future generations to meet their own needs" to apply it to forests.

\section{Criteria and indicators}

The implementation of SFM is generally achieved using criteria and indicators (C\&I). Criteria are categories of conditions or processes whereby sustainable forest management can be assessed, whereas quantitative indicators are chosen to provide measurable features of the criteria and can be monitored periodically to detect trends (Brand, 1997; Wijewardana, 2008) and qualitative indicators are developed to describe the overall policies, institutions and instruments regarding SFM (Forest Europe, 2011).

Different studies have pointed out the main characteristics of a good indicator. Thus, Prabhu et al. (2001) suggested seven attributes to improve the quality of indicators (precision of definition, diagnostic specificity, sensitivity to change or stress, ease of detection, recording and interpretation, ability to summarize or integrate information, reliability and appeal to users), whereas Dale \& Beyeler (2001) established eight prerequisites to selection (ease of measurement, sensitivity to stresses on the system, responsive to stress in a predictable manner, anticipatory, able to predict changes that can be averted by management actions, integrative, known response to disturbances, anthropogenic stresses and changes over time, and low variability in response).

Although several criticisms have been launched against the C\&I system (Bass, 2001; Gough et al., 2008; Poore, 2003; Prabhu et al., 2001), the popularity of the system is evident from the effort invested in its development in recent decades and from the large number of countries that are implementing their own sets of C\&I within the framework of the nine international or regional process (African Timber Organization [ATO], Dry Forest in Asia, Dry Zone Africa, International Tropical Timber Organization [ITTO], Lepaterique of Central America, Montreal Process, Near East, Pan-European Forest [also known as the Ministerial Conference on the Protection of Forest in Europe, MCPFE] and Tarapoto of the Amazon Forest). Nevertheless, three of these processes stand out against the others ${ }^{2}$, namely the ITTO, MCPFE and Montreal processes. The first set of C\&I was developed by ITTO (1992) for sustainable management of tropical forest, and subsequently an initiative to develop C\&I for sustainable management of boreal and temperate forests took place in Canada, under the supervision of the Conference on Security and Cooperation, in 1993. This first initiative reached a general consensus about the guidelines that should be

\footnotetext{
2 Together, these three international C\&I processes represent countries where more than $90 \%$ of the world's temperate and boreal forests, and $80 \%$ of the world's tropical forests are located.
} 
followed by all participating countries. It was then decided that the countries should be split into two groups: European would establish the MCPFE and non-European countries the Montreal processes. The MCPFE process adopted a first draft of C\&I in the first expert level follow-up meeting in Geneva in June 1994, which took shape in Resolution L2 adopted at the third Ministerial Conference on the Protection of Forest in Europe held in Lisbon (MCPFE, 1998), and improved at the subsequent Ministerial Conference held in Vienna (MCPFE, 2003). On the other hand, the Montreal process established its set of C\&I in the Santiago Agreement (1995), with Criteria 1-6 improved at the 18th meeting in Buenos Aires, Argentina (TAC, 2007) and criterion 7 improved at the 20th meeting in Jeju, Republic of Korea (TAC, 2009).

Although the different processes have very different origins and have developed their own criteria, there are some similarities between the three major SFM programs (Table 1). The main difference concerns criterion 7, developed by the Montreal process (Legal, policy and institutional framework), which was imbedded within each of the criteria in the MCPFE process (McDonald \& Lane, 2004) and the concept of which is similar to criterion 1 in the ITTO process (Enabling condition). One important difference between ITTO and the other two processes is that the former does not consider maintenance of the forest contribution to global carbon cycles.

\begin{tabular}{|l|l|l|}
\hline \multicolumn{1}{|c|}{ ITTO process } & \multicolumn{1}{|c|}{ MCPFE process } & \multicolumn{1}{c|}{ Montreal process } \\
\hline $\begin{array}{l}\text { C1. Enabling } \\
\text { condition }\end{array}$ & $\begin{array}{l}\text { C1. Maintenance and appropriate } \\
\text { enhancement of forest resources and } \\
\text { their contribution to global carbon } \\
\text { cycles }\end{array}$ & $\begin{array}{l}\text { C1. Conservation of biological } \\
\text { diversity }\end{array}$ \\
\hline $\begin{array}{l}\text { C2. Extent and } \\
\text { condition of forests }\end{array}$ & $\begin{array}{l}\text { C2. Maintenance of forest ecosystem } \\
\text { health and vitality }\end{array}$ & $\begin{array}{l}\text { C2. Maintenance of productive } \\
\text { capacity of forest ecosystems }\end{array}$ \\
\hline $\begin{array}{l}\text { C3. Forest ecosystem } \\
\text { health }\end{array}$ & $\begin{array}{l}\text { C3. Maintenance and encouragement } \\
\text { of productive functions of forests } \\
\text { (wood and non-wood) }\end{array}$ & $\begin{array}{l}\text { C3. Maintenance of forest } \\
\text { ecosystem health and vitality }\end{array}$ \\
\hline $\begin{array}{l}\text { C4. Forest } \\
\text { production }\end{array}$ & $\begin{array}{l}\text { C4. Maintenance, conservation and } \\
\text { appropriate enhancement of } \\
\text { biological diversity in forest } \\
\text { ecosystems }\end{array}$ & $\begin{array}{l}\text { C4. Conservation and } \\
\text { maintenance of soil and water } \\
\text { resources }\end{array}$ \\
\hline $\begin{array}{l}\text { C5. Biological } \\
\text { diversity }\end{array}$ & $\begin{array}{l}\text { enhancement of protective functions } \\
\text { in forest management (notably soil } \\
\text { and water) }\end{array}$ & $\begin{array}{l}\text { C5. Maintenance of forest } \\
\text { contribution to global carbon } \\
\text { cycles }\end{array}$ \\
\hline $\begin{array}{l}\text { C6. Soil and water } \\
\text { protection }\end{array}$ & $\begin{array}{l}\text { C6. Maintenance of other } \\
\text { socioeconomic functions and } \\
\text { conditions }\end{array}$ & $\begin{array}{l}\text { C6. Maintenance and } \\
\text { enhancement of long-term } \\
\text { multiple socio-economic } \\
\text { benefits to meet the needs of } \\
\text { societies }\end{array}$ \\
\hline $\begin{array}{l}\text { C7. Economic, social } \\
\text { and cultural aspects }\end{array}$ & institutional framework \\
\hline
\end{tabular}

Table 1. Criteria for sustainable forest management: comparison of three major programs 
Other differences in indicators developed by the different processes have become apparent, and e.g. Hickey \& Innes (2008) established more than 2000 separate indicators using the context analysis method. There are also substantial differences as regards the three major processes: the MCPFE process has 52 indicators (MCPFE, 2003), whereas the Montreal process has reduced the number of indicators from 67 (Santiago Agreement, 1995) to 54 (TAC, 2009), and the ITTO process has reduced the number of indicators from 66 in the first revision (ITTO, 1998) to the 56 considered at present (ITTO, 2005).

In light of the proliferation of C\&I processes, the need to achieve harmonization has been widely recognised (Brand, 1997; Castañeda, 2000). Although the concept of harmonization is subject to several interpretations, harmonization should not be mistaken for standardization (Rametsteiner, 2006). Köhl et al (2000) has claimed that "harmonization should be based on existing concepts which should be brought together in a way to be more easy to compare, which could be seen as a bottom up approach starting from an existing divergence and ending in a state of comparability". Although there is not yet a common approach, considerable efforts have been made since the first expert meeting on the harmonization of Criteria and Indicators for SFM, held in Rome in 1995 (FAO, 1995), towards the search for a harmonization/collaboration among C\&I processes through the Inter-Criteria and Indicator Process Collaboration Workshop (USDA, 2009). Advances in harmonization will minimise costs (avoiding duplication and preventing overlap), facilitate comparisons between countries and, overall, improve the credibility of SFM.

Although indicators are increasingly used, their utility is still controversial. Some authors have pointed out several weaknesses of the indicators, e.g. that they are often highly idealistic (Bass, 2001; Michalos, 1997), that they are a pathological corruption of the reductionist approach to science (Bradbury, 1996) or even that the same indicator may lead to contradictory conclusions according to the criterion and the scale. Nevertheless, there is general agreement that the advantages of the approach outweigh these limitations and that researchers should focus their efforts on testing the current indicators and searching for new indicators.

There are two key aspects involved in improving the current and future indicators, the use of a suitable scale and the establishment of a specific interpretation of each indicator. Although these have mainly been implemented at a national level, sub-national and forest management unit (FMU) levels are essential to assess SFM (Wijewardana, 2008). The FMU level has been considered as the finest scale in C\&I processes. However it is well-known that for some indicators (mainly biodiversity indicators), another subdivision within this level may be necessary, such as plot, landscape and spatial levels, for correct interpretation (Barbaro et al., 2007; Heikkinen et al., 2004). In light of this level of precision and the fact that values of indicators are sometimes correlated with several different scales, managers and researchers should establish the most effective scale in each case, to avoid additional charges. Moreover, good indicators are not always easy to interpret in terms of sustainability, because most indicators do not exhibit a clear distinction/threshold between sustainability and unsustainability. In such cases, the achievement of sustainability should be considered on the basis of relative improvement in the current status of the indicator in question (Bertrand et al., 2008).

On the other hand, the scientific community must search for new indicators. Gaps in knowledge have been identified, and as these mainly involve ecological aspects, researchers should go further in investigating the relationships between type of forest management and 
ecological and socioeconomic functions. Thus, managers and researchers, with the support of scientific knowledge and public consultations, should be able to determine feasible goals, from socioeconomic and scientific points of view, since goals that are too pretentious may lead to a situation whereby SFM will not be promoted (Michalos, 1997). Only then can successful selection of new indicators of SFM be achieved.

\section{Forest certification}

In addition to the efforts of different states to develop C\&I in the last two decades, a parallel process has been developed to promote SFM. This process is termed "forest certification". Forest certification can be defined by a voluntary system conducted by a qualified and independent third party who verifies that forest management is based on a predetermined standard and identifies the products with a label. The standard is based on the C\&I approach and the label, which can be identified by the consumer, is used to identify products. Therefore, the two main objectives of forest certification are to improve forest management (reaching SFM) and to ensure market access for certified products (Gafo et al., 2011).

The first certification was carried out in Indonesia in 1990 by the SmartWood programme of the Rainforest Alliance (Crossley, 1995, as cited in Elliot, 2000). However forest certification became popular after The Earth Summit in Rio de Janeiro in 1992. Although important advances were reached at this summit, the failure to sign a global convention on forestry led environmental and non-governmental organizations to establish private systems of governance to promote SFM. In 1993, an initiative led by environmental groups, foresters and timber companies resulted in creation of the Forest Stewardship Council (FSC). Subsequently, other initiatives at international and national levels gave rise to many other schemes, e.g. the Programme for the Endorsement of Forest Certification (PEFC, previously termed Pan European Forest Certification), the Canadian Standards Association (CSA), the Sustainable Forestry Initiative (SFI), the Chile Forest Certification Corporation (CERTFOR) and the Malaysian Timber Certification Council, among others.

The area of certified forest increased rapidly in the 1990s and from then on more gradually, reaching 375 million hectares in May 2011 (UNENCE/FAO, 2011), which represents almost $10 \%$ of the global forest area. Although many forest certification systems were developed in the 1990s, only two schemes (PEFC and FSC) have been used for most of the forest currently certified throughout the world. The FSC scheme was established in 1993 to close the gap identified after the Earth Summit, and with more than 140 million hectares is the first program in terms of number of certified countries (81 countries) and the second system in terms of certified area at the moment (FSC, 2011). The PEFC scheme was established in 1999 as an alternative to the FSC scheme, and was led by European forest owners, who considered that FSC standards mainly applied to large tropical forests, but were inappropriate for small forest owners of European temperate forests. The PEFC scheme has gained importance because it endorses 30 national forest certification systems (Australian Forestry Standard, CSA, SFI, CERTFOR, etc.), and with more than 230 million hectares of certified forests is currently the largest forest certification system (PEFC, 2011). Although several authors have reported significant differences between FSC and PEFC (Clark \& Kozar, 2011; Rotherham, 2011; Sprang, 2001), detailed analysis has revealed that FSC and PEFC are highly compatible, despite having arrived at their C\&I by different routes (ITS Global, 2011). 
Although forest certification began in tropical forests, the trend has changed and the scheme is now carried out in boreal and temperate forests. Almost $90 \%$ of forests certified by the two major programs (FSC and PEFC) are located within Europe and North America (Figure 2). More than half (54\%) of the forests in Europe (excluding the Russian Federation) have already been certified, and almost one third of the forest area in North America has been certified (Figure 3). On the contrary, only about $1.5 \%$ of the forests in Africa, Asia, and Central and South America have been certified (Figure 3), despite the fact that more of half of the world's forests and almost $60 \%$ of primary world forests are located in these countries. The FSC and PEFC schemes display similar patterns of certification, since both mainly certify forests in Europe and North America. However, although the percentage of forest area certified by FSC in Africa, Asia, and Central and South America is only $16 \%$ of all certifications carried out by this scheme, this represents $75 \%$ of the forest areas certified in these regions. Furthermore, almost all certifications carried out in the Russian Federation are carried out by the FSC, whereas the PEFC has certified very few forests in this region. On the other hand, most forest certifications in Europe (excluding the Russian Federation) and North America have been carried out by PEFC (Figure 2).

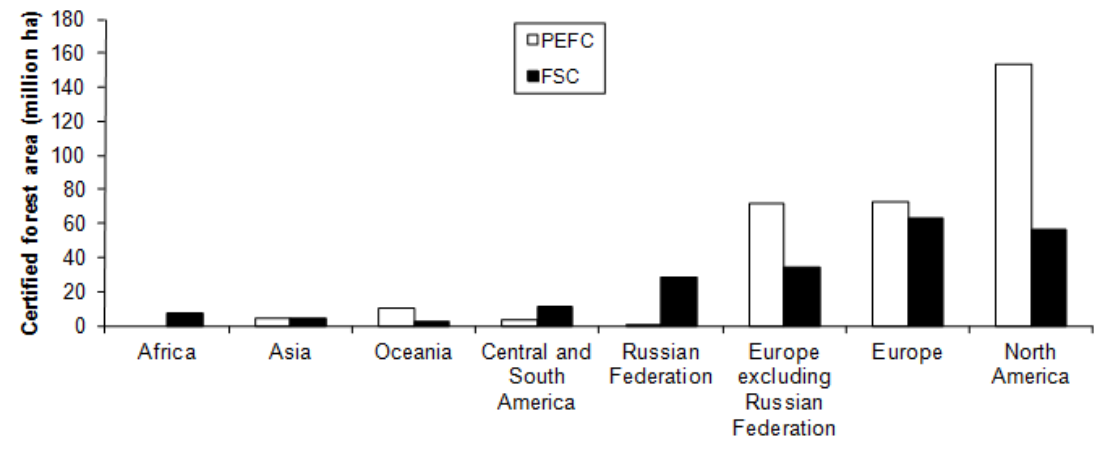

Fig. 2. Global FSC and PEFC certified forest area November 2011 - subregional breakdown (Source: FSC, 2011; PEFC, 2011)

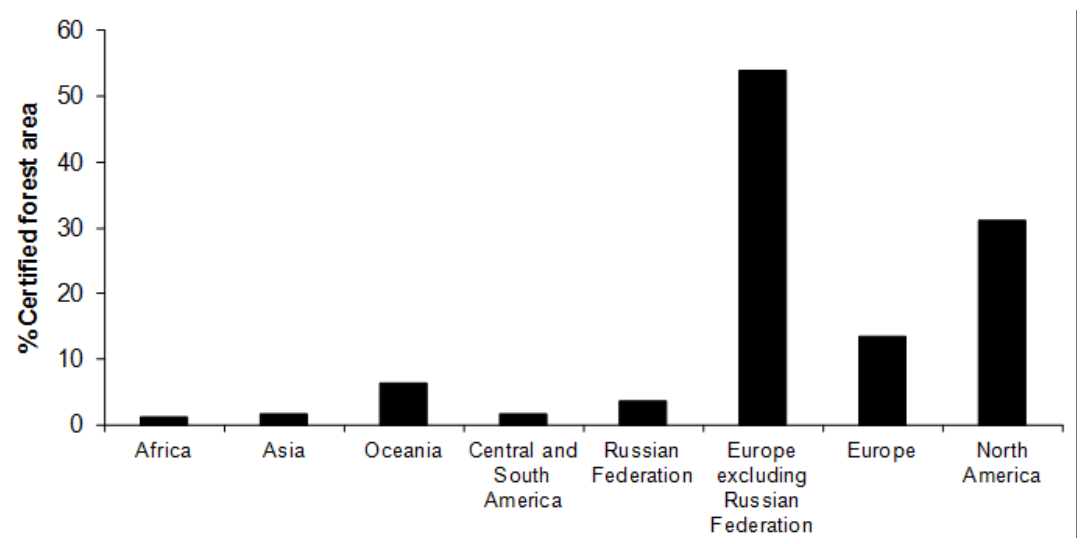

Fig. 3. Percentage of certified forest area, by both FSC and PEFC schemes, November 2011 subregional breakdown (Source: FSC, 2011; PEFC, 2011) 
Forest certification has became very popular, mainly because it is regarded it as a tool whereby everyone should benefit (win-win situation): forest owners should have an exclusive market with premium prices, the forest industry should improve its green corporate image, should not be held responsible for deforestation, and should have available a market tool, consumers should be able to use forest products with a clear conscience, and overall, forests should be managed sustainably.

The concept of forest certification is based on an economic balance, where forest owners and the forest industry place sustainable products on the market in the hope that consumers will be willing to pay the extra cost implied by SFM. Nevertheless, forest certification is still far from reaching its initial goal (win-win), since the expected price increases have not occurred (Cubbage et al., 2010; Gafo et al., 2011). In practice, only consumers and the forest industry have benefited; consumers use certified forest products with a clear conscience, and the forest industry has ensured market access without any great extra cost because this has mainly been assumed by forest owners.

This leads to a difficult question, namely, are forests benefiting from forest certification? It appears logical to believe that forest certification is beneficial to forests, since forest owners must demonstrate that the forests are being managed sustainably. Nevertheless, in depthanalysis reveals a different picture. As already noted, forest certification began in tropical forests with the aim of decreasing deforestation. However, nowadays almost all certified forests are located in developed countries. Furthermore, most of these forests are productive forests, such as single-species and even-aged forests or plantations, in which only small changes must be made to achieve forest certification, while primary forests have largely been ignored. The fact that foresters are able to place certified products from productive forests on the market, with a small additional charge compared to the extra charge involved in certifying products from primary forests hinders certification of the latter, which are actually the most endangered forests. Moreover, this disadvantage may favour unsustainable management, such as illegal logging or in extreme cases conversion of forest land to agricultural land, to favour market competitiveness. Against this background, other initiatives beyond of forest certification has been implemented, such as the FLEGT (Forest Law Enforcement, Governance and Trade) Action Plan of the European Union that provides a number of measures to exclude illegal timber from markets, to improve the supply of legal timber and to increase the demand for wood coming from responsibly managed forests (www.euflegt.efi.int) or the REDD (Reducing Emissions from Deforestation and Forest Degradation) initiative of the United Nations to create a financial value for the carbon stored in forests, offering incentives for developing countries to reduce emissions from forested lands and invest in low-carbon paths to sustainable development, including the role of conservation, sustainable management of forests and enhancement of forest carbon stocks (www.un-redd.org).

In addition, some environmental organizations now consider that plantations should not be certified, since they consider that plantations are not real forests. Such organizations also denounce the replacement of primary forests with plantations in developing countries (WRM, 2010). Although the replacement of primary forests with plantations is a damaging process, replacement of degraded areas such as abandoned pasture or agricultural land provides obvious advantages from economic and ecological points of view (Brockerhoff et al., 2008; Carnus et al., 2006; Hartley, 2002). The two most important schemes (FSC and PECF) approve the certification of forest plantations because they believe that the promotion of wood products from plantations will help to reduce the pressure on primary forests. The 
FSC has added another principle (Principle 10: Plantations) in an attempt to ensure SFM in plantations, while the PECF considers that its criteria and indicators are sufficient to ensure the sustainability of planted forests. The FORSEE project was carried out in order to test the suitability of MCPFE indicators (which are used as the basis for PEFC certification in Europe) for planted forests at a regional level in eight Atlantic regions of Europe (Tomé \& Farrell, 2009). This project concluded that with few exceptions, the MCPFE criteria and indicators appear suited to assess the sustainable management of forests, although it was pointed out that they should be considered as a blueprint for true SFM and adaptations are needed at the local level (Martres et al., 2011).

The viability of tropical forest certification will depend on forest owners obtaining premium prices that at least cover the certification costs, taking into account that these costs vary according to the type of forest (primary forest, plantations, etc.) and that consumers' willingness to pay premium prices will also differ. It should be possible for consumers to distinguish the origin of each product, and in other words different labels are required. Nevertheless, the use of different eco-labels is controversial, since many labels may confuse rather than help consumers. Teisl et al (2002) noted that consumers "seem to prefer information presented in a standardized format so that they can compare the environmental features between products" and highlighted "the need for education efforts to both publicize and inform consumers about how to use and interpret the eco-labels". Both of these are difficult tasks when different certifiers are rivals in the market place.

Without standardization and a powerful information campaign, most environmentally concerned consumers will probably demand wood from sustainably managed forests, without taking into account the type of certification label, and will choose the least expensive product (Teisl et al., 2002). This may entail a new associated problem, since producers and industries will probably also choose the bodies that certify forests most readily and at the lowest cost. This may lead to a situation where the certification schemes would tend to compete with each other and standards would be reduced to attract producers, as pointed out by Van Dam (2001).

\section{Conclusion}

Sustainable forest management is evolving with public awareness and scientific knowledge, and the sustainability concept must be revised to reflect the new reality generated by climate change, where a past reference point shouldn't be considered. Therefore, C\&I should be updated continuously to be able to cope with the climate change challenge and assess sustainability of changing ecosystems. Furthermore, harmonization of C\&I processes would be the most desirable outcome, since this would improve the credibility of the schemes.

On the other hand, forest certification has failed to avoid deforestation and has got two main challenges;

(1) to certify the forests that are most important in ecological terms and that are most susceptible to poor forest management, such as tropical forests and, to a lesser extent, non productive forest in boreal and temperate regions, and (2) to achieve a market with premium prices, in which the win-win concept will prevail. This will require educational campaigns and a higher level of credibility for labels. Moreover, parallel initiatives, such as FLEG and REDD, considering outside forest sector drivers leading to deforestation should be taking into account to limit this process. 


\section{Acknowledgment}

The authors thank Christophe Orazio for helpful comments on earlier versions of the manuscript.

\section{References}

Barbaro, L.; Rossi, J-P.; Vetillard, F.; Nezan, J. \& Jactel, H. (2007). The spatial distribution of birds and carabid beetles in pine plantation forests: the role of landscape composition and structure. Journal of Biogeography, Vol. 34, pp. 652-664.

Bass, S. (2001). Policy inflation, capacity constraints: can criteria and indicators bridge the gap? In: Criteria and Indicators of Sustainable Forest Management, R.J. Raison; A.G. Brown \& D.W. Flinn (Eds.), 19-37. IUFRO research series, Vol. 7. CABI Publishing, Oxford.

Bertrand, N.; Jones, L.; Hasler, B.; Omodei-Zorini, L.; Petit, S. \& Contini, C. (2008). Limits and targets for a regional sustainability of assessment: an interdisciplinary exploration of the threshold concept. In: Sustainability Impact Assessment of Land Use Changes, K. Helming; M. Pérez-Soba \& P. Tabbush (Eds.), 405-424. Springer, Berlin.

Bradbury, R. (1996). Are indicators yesterday's news? Proceedings of the Fenner Conference "Tracking progress: Linking environment and economy through indicators and accounting systems", pp. 1-8. Sydney, University of New South Wales.

Brand, D.G. (1997). Criteria and indicators for the conservation and sustainable management of forests: progress to date and future directions. Biomass and Bioenergy, Vol. 13, Nos. 4/5, pp. 247-253.

Brockerhoff, E.; Jactel, H.; Parrotta, J.A.; Quine, C.P.; Sayer, J. (2008). Plantation forests and biodiversity: oxymoron or opportunity? Biodiversity and Conservation 17: 925-951.

Carnus, J-M.; Parrotta, J.; Brockerhoff, E.; Arbez, M.; Jactel, H.; Kremer, A.; Lamb, D.; O'Hara, K. \& Walters, B. (2006). Planted forests and biodiversity. Journal of Forestry, Vol. 104, No. 2, pp. 65-77.

Castañeda, F. (2000). Criteria and indicators for sustainable forest management: international processes current status and the way ahead. Unasylva, Vol. 203 (51), No. 4, pp. 34-40.

Clark, M.R. \& Kozar, J.S. (2011). Comparing sustainable forest management certifications standards: a meta-analysis. Ecology and Society, Vol. 16, No 1, Art. 3.

Cubbage, F.; Diaz, D.; Yapura, P. \& Dube, F. (2010). Impacts of forest management certification in Argentina and Chile. Forest Policy and Economics, Vol. 12, pp. 497504.

Dale, V.H. \& Beyeler, S.C. (2001). Challenges in the develpment and use of ecological indicators. Ecological indicators, Vol. 1, pp. 3-10.

Elliot, C. (2000). Forest certification: A policy perspective. CIFOR, ISBN 979-8764-56-0. Bogor, Indonesia. 
FAO (1995). Report of the expert meeting on the harmonization of criteria and indicators for sustainable forest management. Food and Agricultural Organization of the United Nations, Rome, Italy.

FAO (2010). Global forest resources assessment, 2010 - Main report. Food and Agricultural Organization of the United Nations Forestry Paper 163, Rome, Italy. Availability from

http://www.fao.org/forestry/fra/fra2010/en/ [Accessed November 2011]

FAO (2011). State of the World's forests 2011. Food and Agricultural Organization of the United Nations, Rome, Italy. Availability from http:/ / www.fao.org/docrep/013/i2000e/i2000e00.htm [Accessed November 2011].

Forest Europe (2011) State of Europe's Forests 2011. Status and Trends in Sustainable Forest Management in Europe. Forest Europe, United Nations Economic Commission for Europe. Food and Agriculture Organization, Oslo, Norway, 337 pp. Availability from

http://www.foresteurope.org/pBl7xY4UEJFW9S_TdLVYDCFspY39Ec720U9or6XP.ips

[Accessed February 2012]

FSC (2011). Global Forest Stewardship Council certifies: type and distribution. Availability from http:/ / www.fsc.org/facts-figures.html [Accessed November 2011].

Gafo, M.; Caparros, A. \& San-Miguel, A. (2011). 15 years of forest certification in the European Union. Are we doing things right? Forest Systems, Vol. 20, No. 1, pp. 8194.

Gough, A.D.; Innes, J.L. \& Allen, S.D. (2008). Development of common indicators of sustainable forest management. Ecological indicators, Vol. 8, pp. 425-430.

Hartley, M.J. (2002). Rationale and methods for conserving biodiversity in plantation forests. Forest Ecology and Management, Vol. 155, pp. 81-95.

Heikkinen, R.K.; Luoto, M.; Virkkala, R. \& Rainio, K. (2004). Effects of habitat cover, landscape structure and spatial variables on the abundance of birds in an agricultural-forest mosaic. Journal of Applied Ecology, Vol. 41, pp. 824835.

Hickey, G.M. \& Innes, J.L. (2008). Indicators for demonstrating sustainable forest management in British Columbia, Canada: An international review. Ecological indicators, Vol. 8, pp. 131-140.

ITTO (1992). Criteria for the measurement of sustainable tropical forest management. International Tropical Timber Organization Policy Development. Series No. 3. Yokohama, Japan.

ITTO (1998). Criteria and indicators for sustainable management of natural tropical forests. International Tropical Timber Organization Policy Development. Series No. 7. Yokohama, Japan.

ITTO (2005). Revised ITTO criteria and indicators for the sustainable management of tropical forests including reporting format. International Tropical Timber Organization Policy Development. Series No. 15. Yokohama, Japan. 
ITS Global (2011). Forest certification - Sustainability, governance and risk. International Trade Strategies, January 2011. Availability from http://www.itsglobal.net/sites/default/files/itsglobal/Forestry\%20CertificationSustainability \%20Governance \%20and\%20Risk\%20\%282011\%29.pdf [Accessed November 2011].

Köhl, M.; Traub, G. \& Päivinen, R. (2000). Harmonisation and standardisation in multinational environmental statistics- mission impossible?. Environmental Monitoring and Assessment, Vol. 63, pp. 361-380.

Martres, J-L.; Carnus, J-M. \& Orazio, C. (2011). Are MCPFE indicators suitable for planted forests? European Forest Institute Discussion paper No. 16. Availability from http://www.efi.int/files/attachments/publications/efi_dp16.pdf [Accessed November 2011]

McDonald, C.T. \& Lane, M.B. (2004). Converging global indicators for sustainable forest management. Forest Policy and Economics. Vol. 6, pp. 63-70.

MCPFE (1993). General declaration and resolutions adopted. In: Proceedings of the Second Ministerial Conference on the Protection of Forest in Europe, Helsinki, 1993. Report. Liaison Unit, Vienna.

MCPFE (1998). General declaration and resolutions adopted. In: Proceedings of the Third Ministerial Conference on the Protection of Forests in Europe, Lisbon, 1998. Report. Liaison Unit Vienna.

MCPFE (2003). General declaration and resolutions adopted. In: Proceedings of the Fourth Ministerial Conference on the Protection of Forest in Europe, Vienna, 2003. Report. Liaison Unit, Vienna.

Michalos, A.C. (1997). Combining social, economic and environmental indicators to measure sustainable human well-being. Social Indicators Research, Vol. 40, pp. 221-258.

PECF (2011). Programme for the Endorsement of Forest Certification. Caring for our forests globally. Availability from http://pefc.org/about-pefc/who-we-are/facts-a-figures [Accessed November 2011].

Peng, C. (2000). Understanding the role of forest simulation models in sustainable forest management. Environmental Impact Assessment Review, Vol 20, pp. 481501.

Poore, D. (2003). Changing Landscapes. Earthscan, ISBN 1-85383-991-4. London, UK.

Prabhu, R.; Ruitenbeek, H.J.; Boyle, T.J.B. \& Colfer, C.J.P. (2001). Between voodoo science and adaptive management: the role and research needs for indicators of sustainable forest management. In: Criteria and Indicators of Sustainable Forest Management, R.J. Raison; A.G. Brown \& D.W. Flinn (Eds.), 39-66. IUFRO research series, Vol. 7. CABI Publishing, Oxford.

Rametstenier, E. (2006). Opportunities to Create Synergy Among the C\&I Processes Specific to the Topic of Harmonization. Inter-C\&I Process Harmonization Workshop. Collaboration Among C\&I Process - ITTO/FAO/MCPFE. Appendix 3 - Workshop Papers. Pp. 11-22. Bialowieza, Poland. 
Rothertham, T. (2011). Forest management certification around the world - Progress and problems. The Forestry Chronicle, Vol. 87, No. 5, pp. 603-611.

Santiago Agreement (1995). Criteria and indicators for the conservation and sustainable management of temperate and boreal forests (The Montreal Process). Journal of Forestry. Vol. 93, No. 4, pp. 18-21.

Sprang, P. (2001). Aspects of quality assurance under the certification schemes FSC and PEFC. PhD thesis University of Freiburg, German. 70 pp. Availability from http://www.rainforest-alliance.org/forestry/documents/aspects.pdf [Accessed November 2011].

TAC (Technical Advisory Committee) (2007). Montreal Process Criteria and Indicators for the Conservation and Sustainable Management of Temperate and Boreal Forests. Technical notes on implementation of the Montreal Process Criteria and Indicators. Criteria 1-6. 2nd Edition. Availability from

http://www.rinya.maff.go.jp/mpci/meetings/an-4.pdf [Accessed November 2011].

TAC (Technical Advisory Committee) (2009). Montreal Process Criteria and Indicators for the Conservation and Sustainable Management of Temperate and Boreal Forests. Technical notes on implementation of the Montreal Process Criteria and Indicators. Criteria 1-7. 3rd Edition. Availability from http://www.rinya.maff.go.jp/mpci/2009p_2.pdf [Accessed November 2011].

Teisl, M.F.; Peavey, S.; Newman, F.; Buono, J. \& Hermann, M. (2002). Consumer reactions to environmental labels for forest products: A preliminary look. Forest Products Journal, Vol. 52, No. 1, pp. 44-50

Tomé, M. \& Farrell, T. (2009). Special issue on selected results of the FORSEE project. Annals of Forest Science, Vol. 66, pp. 300.

UNECE/FAO (2011). Forest products. Annual market review 2010-2011. Geneve timber and forest study paper 27. United Nations, New York and Geneve. Availability from http://www.unece.org/fileadmin/DAM/publications/timber/FPAMR_20102011_HQ.pdf [Accessed November 2011].

USDA (2009). Conference Proceedings: Forest Criteria and Indicators Analytical Framework and Report Workshop. May 19-21, 2008 Joensuu, Finland. Gen. Tech. Report GTR-WO-81. USDA Forest Service, Washington Office. 350 p. Availability from

http://treesearch.fs.fed.us/pubs/gtr/gtr_wo81.pdf

[Accessed November 2011].

Van Dam, C. (2001). The economics of forest certification sustainable development for whom? Paper presented at The Latin American Congress on Development and Environment "Local Challenges of Globalization". Quito, Ecuador, April 11-12, 2003. Availability from http://cdc.giz.de/de/dokumente/en-d74-economics-offorest-certification.pdf [Accessed November 2011].

Wang, S. \& Wilson, B. (2007). Pluralism in the economics of sustainable forest management. Forest Policy and Economics, Vol. 9, pp. 743-750.

Wiersum, K.F. (1995). 200 years of sustainability in forestry: lessons from history. Environmental Management, Vol. 19, No 4, pp. 321-329. 
Wijewardana, D. (2008). Criteria and indicators for sustainable forest management: The road traveled and the way ahead. Ecological indicators, Vol. 8, pp. 115-122.

WRM (2010). Tree monocultures in the South. World Rainforest Movement Bulletin Issue No 158, pp. 13-29. Availability from

http://www.wrm.org.uy/index.html [Accessed November 2011]. 


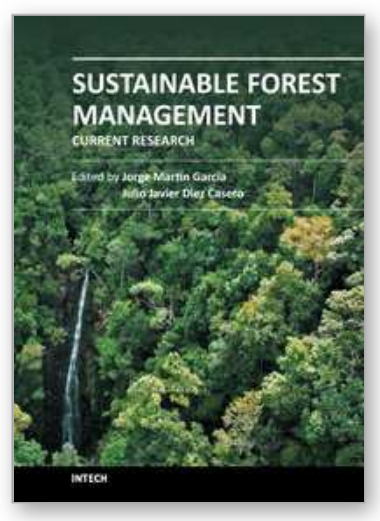

\author{
Sustainable Forest Management - Current Research \\ Edited by Dr. Julio J. Diez
}

ISBN 978-953-51-0621-0

Hard cover, 454 pages

Publisher InTech

Published online 23, May, 2012

Published in print edition May, 2012

Sustainable forest management (SFM) is not a new concept. However, its popularity has increased in the last few decades because of public concern about the dramatic decrease in forest resources. The implementation of SFM is generally achieved using criteria and indicators (C\&I) and several countries have established their own sets of C\&I. This book summarises some of the recent research carried out to test the current indicators, to search for new indicators and to develop new decision-making tools. The book collects original research studies on carbon and forest resources, forest health, biodiversity and productive, protective and socioeconomic functions. These studies should shed light on the current research carried out to provide forest managers with useful tools for choosing between different management strategies or improving indicators of SFM.

\title{
How to reference
}

In order to correctly reference this scholarly work, feel free to copy and paste the following:

Jorge Martín-García and Julio Javier Diez (2012). Sustainable Forest Management: An Introduction and Overview, Sustainable Forest Management - Current Research, Dr. Julio J. Diez (Ed.), ISBN: 978-953-510621-0, InTech, Available from: http://www.intechopen.com/books/sustainable-forest-management-currentresearch/sustainable-forest-management-an-introduction-and-overview

\section{INTECH}

open science | open minds

\author{
InTech Europe \\ University Campus STeP Ri \\ Slavka Krautzeka 83/A \\ 51000 Rijeka, Croatia \\ Phone: +385 (51) 770447 \\ Fax: +385 (51) 686166 \\ www.intechopen.com
}

\author{
InTech China \\ Unit 405, Office Block, Hotel Equatorial Shanghai \\ No.65, Yan An Road (West), Shanghai, 200040, China \\ 中国上海市延安西路65号上海国际贵都大饭店办公楼 405 单元 \\ Phone: +86-21-62489820 \\ Fax: +86-21-62489821
}


(C) 2012 The Author(s). Licensee IntechOpen. This is an open access article distributed under the terms of the Creative Commons Attribution 3.0 License, which permits unrestricted use, distribution, and reproduction in any medium, provided the original work is properly cited. 